\title{
The Western Australian Museum/Woodside Energy Ltd. Partnership to explore the marine biodiversity of the Dampier Archipelago, Western Australia
}

\author{
Diana S. Jones \\ Western Australian Museum, Locked Bag 49, Welshpool DC, 6986, Western Australia, Australia \\ email: diana.jones museum.wa.gov.au
}

\section{INTRODUCTION}

The Dampier Archipelago is one of the major physical features of the Pilbara coast of northwestern Australia. It lies between latitudes $20^{\circ} 20^{\prime} \mathrm{S}-20^{\circ} 45^{\prime} \mathrm{S}$ and longitudes $116^{\circ} 24^{\prime} \mathrm{S}-117^{\circ} 05^{\prime} \mathrm{E}$ and is situated at the eastern end of an extensive chain of small coastal islands between Exmouth and Dampier (Figures 1 and 2). The Pilbara region is an area of distinctive climate, geology, land forms, soils, vegetation and biota. It is also rich in iron ore and gas and oil reserves. Jones (2004a) provide an introduction to the archipelago, its climate, geology and landform and the marine environments that surround it, as well as the history of its earliest occupation, discovery by western explorers and the modern economic forces that are driving its development. Reviews of the Dampier marine environment and its oceanography have also been provided by Wells and Walker (2003) and Pearce et al. (2003), respectively.

Between 1998 and 2001, the Western Australian Museum/Woodside Energy Ltd Partnership conducted a marine biological survey of the Dampier Archipelago. The survey involved two diving expeditions (1988 and 1999), a dredging expedition (1999), a marine biological workshop (2000) and miscellaneous fieldwork in the archipelago, the Burrup Peninsula and on adjacent continental shores. The diving expeditions mapped and recorded the marine habitats of the entire Archipelago and extensive information and material was collected regarding the marine fauna and flora of the region. The dredging and trawling expedition documented the benthic marine invertebrate biodiversity of northwestern Australia, to compare with that of other areas of Australia. Studies on the marine invertebrates in the mangroves on the Burrup Peninsula and adjacent continental shores provided an opportunity to undertake seasonal studies on the functioning of invertebrates in these systems. The first international marine biological workshop in northwestern Australia was held in Dampier in July and August 2000, where marine scientists pursued individual research projects on a variety of taxa.
The WA Museum/Woodside Energy Ltd partnership (1998-2002) represents the first sampling expeditions to the Dampier Archipelago within the framework of a comprehensive project aimed at studying the biodiversity of the area. Prior to this partnership, the Dampier Archipelago had been the subject of various studies (see Jones 2004a) but no comprehensive study of its marine invertebrates, fishes and marine algae had been attempted.

\section{METHODOLOGY}

Specimens were collected from a total of 120 geopositioned stations throughout the waters of the Dampier Archipelago, by diving and dredging expeditions and by hand collecting on the shores of the islands of the archipelago and along the neighbouring continental shoreline (Jones, 2004b). Under-water videos transects of 60 diving stations and habitat descriptions of all stations were recorded for future reference for monitoring change in an area where substantial industrial development is planned.

Taxa targeted were marine algae, sponges, hard corals, crustaceans, molluscs, echinoderms and fishes, with additional marine invertebrates being sampled opportunistically. Marine reptiles, snakes and mammals were not included in the survey. Researchers attending the international marine biological workshop conducted short, individual, ecological and taxonomic research projects on a miscellaneous variety of taxa (Wells et al., 2003a; 2003b).

In the report of the diving and dredging expeditions (Jones, 2004b), the methodology adopted is described by Hutchins et al. (2004) and habitat descriptions are provided by Hutchins and Berry (2004), Hutchins and Fromont (2004), Morrison (2004) and Slack-Smith (2004). Station maps and lists for the dredging and diving expeditions and shore collecting are detailed at the beginning of the expeditions' report (Jones, 2004b) i.e. diving expeditions DA1/1998 and DA3/1999 (Hutchins and Berry, 2004), dredging expedition 


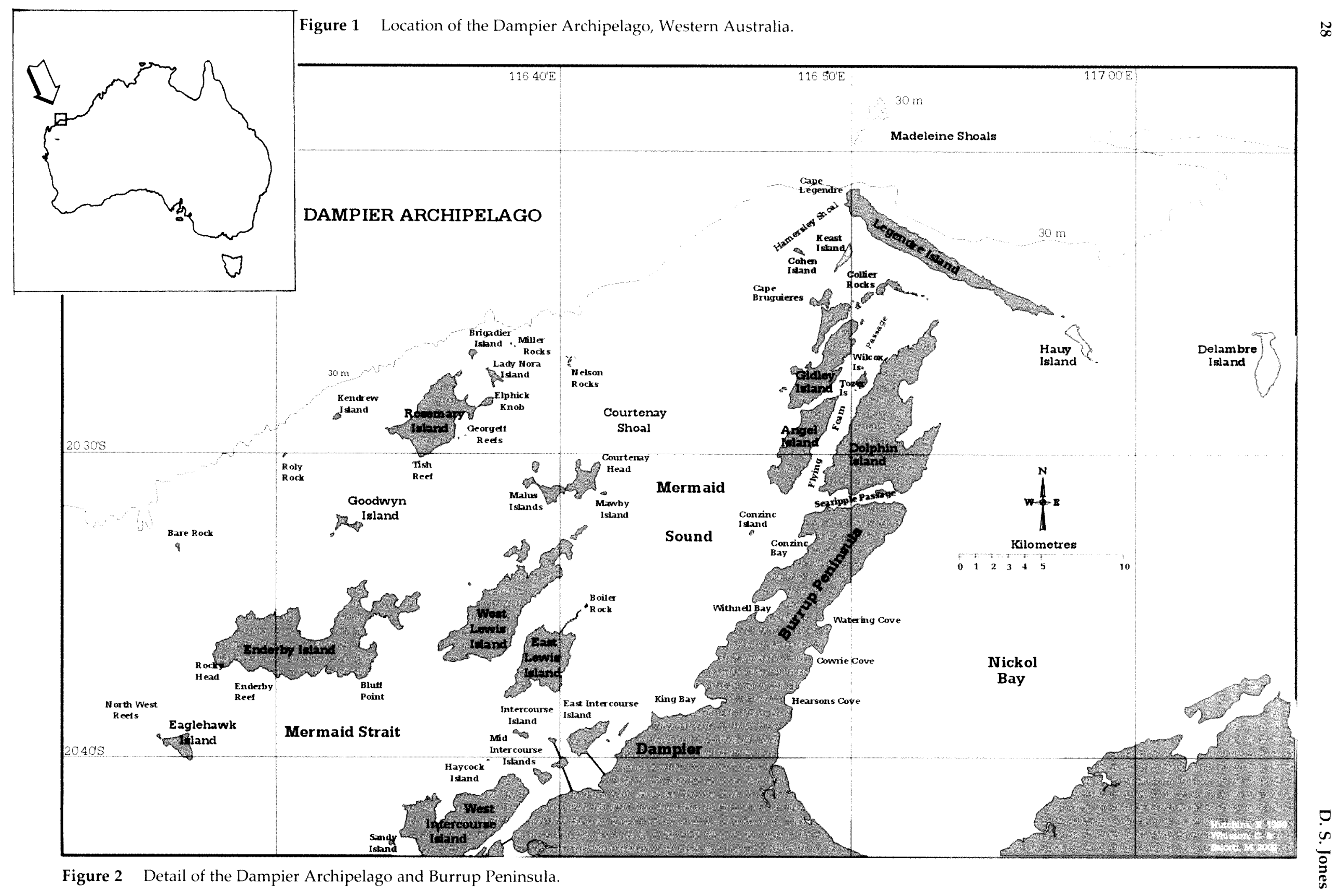


DA2/1999 (Slack-Smith, 2004) and a selected station list for the workshop diving expedition DA4/2000 (Hutchins and Fromont, 2004).

During the diving and dredging expeditions and mangrove fieldwork, scientists collected marine algae, sponges, scleractinian corals, crustaceans, molluscs, echinoderms, minor marine invertebrates and fishes. These results are published in the report of the diving and dredging expeditions (Jones, 2004b) - marine algae (Huisman, 2004), sponges (Fromont, 2004), scleractinian corals (Griffith, 2004), crustaceans (Hewitt, 2004; Jones, 2004c; Peart, 2004), molluscs (Slack-Smith and Bryce, 2004; Taylor and Glover, 2004), echinoderms (Marsh and Morrison, 2004), minor marine invertebrates (Salotti et al., 2004) and fishes (Hutchins, 2004).

The short, specific, ecological and taxonomic studies were reported in the two Workshop volumes (Wells et al., 2003a; 2003b) and included ecological studies on the Mollusca (Britton and Morton, 2003; Glover et al., 2003a; Hickman, 2003; Kohn, 2003a, b; McMahon, 2003; Morton and Britten, 2003; Tan, 2003; Taylor and Glover, 2003; Wells and Lalli, 2003a; Wilson, 2003) and Echinodermata (Wells and Lalli, 2003b). Taxonomic studies included marine benthic flora (Huisman and Borowitzka, 2003), oligochaete worms (Erséus and Wang, 2003; Rota et al., 2003), polychaete worms (Hutchings and Avery, 2003), sponges (Fromont, 2003), molluscs (Brearley et al., 2003; Fahey and Valdés, 2003; Glover et al., 2003b; Seapy et al., 2003; Wilson 2003); barnacles (Jones, 2003), Acari (Bartsch, 2003a, b c; Smit, 2003), infaunal invertebrates (Kohn, 2003c); and fishes (Hutchins, 2003).

Through its wide international scientific networks, the Western Australian Museum involved 85 scientists from 25 countries, five Australian and 14 international museums, seven Australian and 35 international universities and research institutions, and film and documentary makers in the project, along with the nine WA Museum scientists and staff from Woodside's environmental team. Other secondary partners included 19 local and Australian companies, 16 Australian government agencies, and other resource companies and local stakeholders in the area, including the two High Schools. During the course of the project, we were also able to provide career advancement training opportunities for 17 young people.

\section{RESULTS}

Since 1998, this partnership has investigated and documented the marine biodiversity of the Dampier Archipelago, leading to the development of The Woodside Collection. The material has significantly increased the numbers of marine invertebrate and fish specimens collected from the area (Figure 3 ).
Housed in perpetuity at the Western Australian Museum, it contains more than 4,600 species, all fully identified by Australian and international experts. At the time of publication of the present volume, 268 new species have been described and many new species are currently being or still yet to be described. Additionally, 26 species are recorded from Australia for the first time, 116 from Western Australia for the first time, and 411 from the Dampier Archipelago for the first time.

The Woodside Collection represents a unique, perpetual reference to the biodiversity of the waters of northwestern Australia. In addition, it represents a key regional biodiversity repository in a global context, containing a wealth of information relevant to the whole of the vast tropical Indo-Pacific region (from the eastern coast of Africa, across the Indian and Pacific Oceans to Hawaii), thus making it a major data source for the shallow water biota of this region. This information, plus associated scientific and GIS spatial data and photographic images, is also available and accessible as a universal, public reference, on-line facility through the development of the interactive, educational Woodside Collection Website (www.museum.wa.gov.au/dampier). Information has also been made widely available to schools and the general public through other media; two permanent exhibitions; an educational video, Our Backyard, produced with the Western Australian Department of Education, the Curriculum Council and the two High Schools in the region; and the international television documentary, Life on the Edge - Down Under.

The Woodside Collection is already being acknowledged as a unique resource, not only for its enormous diversity and high quality expert identification, but also for the knowledge that it is generating and communicating. It is providing unique information on the biodiversity of the Dampier Archipelago that is facilitating sound environmental management to maintain and conserve the marine resources of the region for future generations, as well as developing strategies to minimize the environmental impact of hydrocarbon exploration and production activities. Results of the partnership's research have substantially modified the map previously used to designate the marine habitats of the Dampier Archipelago and data generated through the partnership have been made available to government, industry, environmental, conservation and fisheries managers in Western Australia. The Woodside Collection provides years of further study, research and dynamic engagement with our communities to enhance their understanding and appreciation of our natural heritage. These data are essential records for Western Australians and for the conservation and management of biodiversity 


\section{Specimens from the Dampier Archipelago}

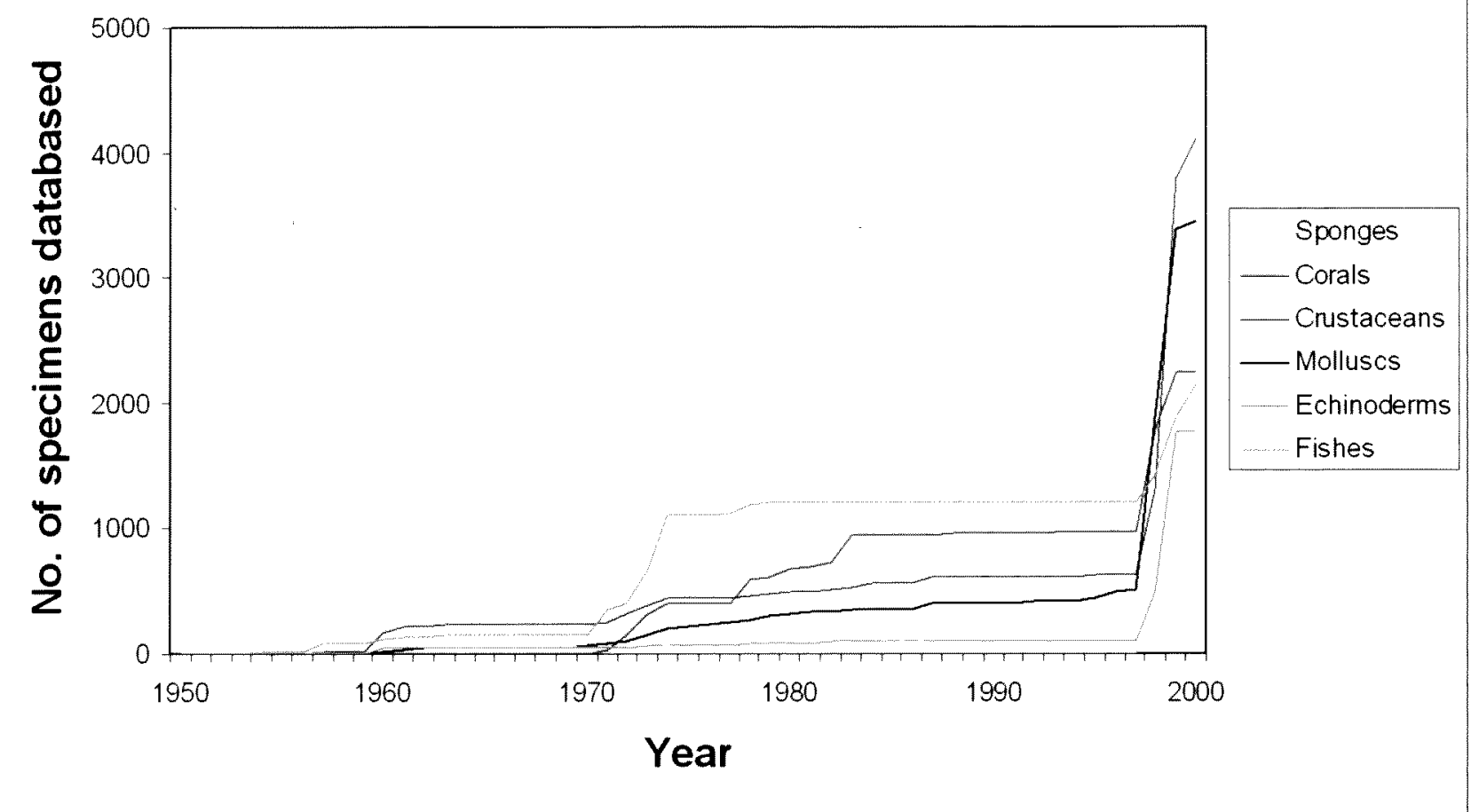

Figure 3 Cumulative graph of specimens collected from the Dampier Archipelago, Western Australia.

in the Dampier Archipelago. The Woodside Collection will continue to provide benefits to government, industry and the scientific and general community for the long term.

The achievements of the Western Australian Museum/Woodside Energy Ltd partnership have been recognized through a number of awards; in 2001, the WA Golden Gecko Award for Environmental Excellence; in 2003, the prestigious City of Sydney Open Award, Australian Business Arts Partnership Awards; and, most recently in 2007, as winner of the state final of the Prime Minister's Award.

\section{Crustacean Report}

The present volume represents the fourth and final report of the series associated with the work of the WA Museum/Woodside Energy Ltd partnership in the waters of the Dampier Archipelago. It specifically documents crustacean groups collected during the partnership that were sent to specialists for specific expert identification.

The methodology adopted and data for diving expeditions (DA1/1998 and DA3/1999), the Workshop diving expedition (DA4/2000, selected station only included) and the dredging expedition (DA2/1999) were previously published in the expeditions' report (Jones, 2004b). These are presented at the beginning of the present report for ease of reference (Methodology, and Tables 1, 2 and 3 , respectively). It should be noted that a complete data set for the Workshop diving expedition (DA4/ 2000) and minor data corrections in Table 1 (DA1/ 1998 and DA3/1999) are included in the present report. Additionally, for completeness, station lists for miscellaneous fieldwork sites in the Dampier Archipelago are also presented in the present volume (Tables 4 and 5).

In the expeditions' report (Jones, 2004b), crustaceans collected during the diving and dredging expeditions were listed by Hewitt (2004), with Cirripedia and Amphipoda reported separately in that volume (Peart, 2004 and Jones, $2004 \mathrm{c}$, respectively). Together with the present contributions, these reports present a comprehensive review of the crustaceans occurring in the waters and on the shores of the Dampier Archipelago and the adjacent continental coastline.

\section{REFERENCES}

Bartsch, I. (2003a). A new species of the brevipalpus group, genus Agauopsis (Halacaridae: Acari) from Dampier, Western Australia: description and key related to species. In Wells, F.E., Walker, D.I. and 
Jones, D.S. (eds), Proceedings of the Eleventh International Marine Biological Workshop: The Marine Flora and Fauna of Dampier, Western Australia 1: 241-254. Western Australian Museum, Perth.

Bartsch, 1. (2003b). Rhombognathine mites (Halacaridae: Acari) from Dampier, Western Australia: taxonomy and biogeography. In Wells, F.E., Walker, D.I. and Jones, D.S. (eds), Proceedings of the Eleventh International Marine Biological Workshop: The Marine Flora and Fauna of Dampier, Western Australia 1: 255-280. Western Australian Museum, Perth.

Bartsch, I. (2003c). A new arenicolous Copidognathus (Halacaridae: Acari) from Dampier, Western Australia: taxonomy and biogeography. In Wells, F.E., Walker, D.I. and Jones, D.S. (eds), Proceedings of the Eleventh International Marine Biological Workshop: The Marine Flora and Fauna of Dampier, Western Australia 1: 281-289. Western Australian Museum, Perth.

Brearley, A, Kashane, C. and Nopadon, K. (2003). Pholadidae and Teredinidae (Mollusca: Bivalvia) collected from mangrove habitats on the Burrup Peninsula, Western Australia. In Wells, F.E., Walker, D.I. and Jones, D.S. (eds), Proceedings of the Eleventh International Marine Biological Workshop: The Marine Flora and Fauna of Dampier, Western Australia 2: 345-362. Western Australian Museum, Perth.

Britton, J.C. and Morton, B. (2003). Connective cooling by the intertidal tropical chiton, Acanthopleura spinosa (Mollusca: Polyplacophora) from rocky intertidal habitat at Watering Cove, Burrup Peninsula, Western Australia. In Wells, F.E., Walker, D.I. and Jones, D.S. (eds), Proceedings of the Eleventh International Marine Biological Workshop: The Marine Flora and Fauna of Dampier, Western Australia 1: 51-68. Western Australian Museum, Perth.

Erséus, C. and Wang, H. (2003). Marine Tubificidae (Oligochaeta) of the Dampier area, Western Australia. In Wells, F.E., Walker, D.I. and Jones, D.S. (eds), Proceedings of the Eleventh International Marine Biological Workshop: The Marine Flora and Fauna of Dampier, Western Australia 2: 363-394. Western Australian Museum, Perth.

Fahey, S. and Valdés, A. (2003). A new species of Platvdoris (Mollusca: Nudibranchia) from NorthWestern Australia. In Wells, F.E., Walker, D.I. and Jones, D.S. (eds), Proceedings of the Eleventh International Marine Biological Workshop: The Marine Flora and Fauna of Dampier, Western Australia 2: 395-404. Western Australian Museum, Perth.

Fromont, J. (2003). Porifera (Sponges) in the Dampier Archipelago: Taxonomic affinities and biogeography. In Wells, F.E., Walker, D.I. and Jones, D.S. (eds), Proceedings of the Eleventh International Marine Biological Workshop: The Marine Flora and Fauna of Dampier, Western Australia 2: 405-418. Western Australian Museum, Perth.

Fromont, J. (2004). Porifera (sponges) of the Dampier Archipelago, Western Australia: habitats and distributions. In Jones, D.S. (ed.), Report on the results of the Western Australia Museum/Woodside Energy Ltd. Partnership to explore the Marine Biodiversity of the Dampier Archipelago, Western Australia 19982002. Records of the Western Australian Museum, Supplement 66: 69-100.

Glover, E.A., Taylor, J.D. and Slack-Smith, S.M. (2003a). A new species and genus of lucinid bivalve from Western Australia (Bivalvia: Lucinidae). In Wells, F.E., Walker, D.I. and Jones, D.S. (eds), Proceedings of the Eleventh International Marine Biological Workshop: The Marine Flora and Fauna of Dampier, Western Australia 2: 419-424. Western Australian Museum, Perth.

Glover, E.A., Taylor, J.D. and Whittaker, J. (2003b). Distribution, abundance and foraminiferal diet of an intertidal scaphopod, Laevidentatum lubricatum, around the Burrup Peninsula, Dampier, Western Australia. In Wells, F.E., Walker, D.I. and Jones, D.S. (eds), Proceedings of the Eleventh International Marine Biological Workshop: The Marine Flora and Fauna of Dampier, Western Australia 1: 224-240 Western Australian Museum, Perth.

Griffith, J.K. (2004). Scleractinian corals collected during 1998 from the Dampier Archipelago, Western Australia. In Jones, D.S. (ed.), Report on the results of the Western Australia Museum/Woodside Energy Ltd. Partnership to explore the Marine Biodiversity of the Dampier Archipelago, Western Australia 19982002. Records of the Western Australian Museum, Supplement 66: 101-120.

Hewitt, M. A. (2004). Crustacea (excluding Cirripedia and Amphipoda) of the Dampier Archipelago, Western Australia. In Jones, D.S. (ed.), Report on the results of the Western Australia Museum/Woodside Energy Ltd. Partnership to explore the Marine Biodiversity of the Dampier Archipelago, Western Australia 1998-2002. Records of the Western Australian Museum, Supplement 66: 169-219.

Hickman, C.S. (2003). Functional morphology and mode of life of Isanda coronata (Gastropoda: Trochidae) in an Australian macrotidal sandflat. In Wells, F.E., Walker, D.I. and Jones, D.S. (eds), Proceedings of the Eleventh International Marine Biological Workshop: The Marine Flora and Fauna of Dampier, Western Australia 1: 69-88. Western Australian Museum, Perth.

Huisman, J.A. (2004). Marine benthic flora of the Dampier Archipelago, Western Australia. In Jones, D.S. (ed.), Report on the results of the Western Australia Museum/Woodside Energy Ltd. Partnership to explore the Marine Biodiversity of the Dampier Archipelago, Western Australia 1998-2002. Records of the Western Australian Museum, Supplement 66: 61-68.

Huisman, J.A. and Borowitzka, M.A. (2003). Marine benthic flora of the Dampier Archipelago, Western Australia. In Wells, F.E., Walker, D.I. and Jones, D.S. (eds), Proceedings of the Eleventh International Marine Biological Workshop: The Marine Flora and Fauna of Dampier, Western Australia 2: 291-344. Western Australian Museum, Perth.

Hutchings, P.A. and Lavery, 1.. (2003). The Terebellidae, Trichobranchidae and Pectinariidade (Polychaeta) of the the Dampier Archipelago, Western Australia. In 
Wells, F.E., Walker, D.I and Jones, D.S. (eds), Proceedings of the Eleventh International Marine Biological Workshop: The Marine Flora and Fauna of Dampier, Western Australia 2: 425-452. Western Australian Museum, Perth.

Hutchins, J.B (2003). Checklist of marine fishes of the Dampier Archipelago, Western Australia. In Wells, F.E., Walker, D.I. and Jones, D.S. (eds), Proceedings of the Eleventh International Marine Biological Workshop: The Marine Flora and Fauna of Dampier, Western Australia 2: 253-478. Western Australian Museum, Perth.

Hutchins, J.B (2004). Fishes of the Dampier Archipelago, Western Australia. In Jones, D.S. (ed.), Report on the results of the Western Australia Museum/Woodside Energy Ltd. Partnership to explore the Marine Biodiversity of the Dampier Archipelago, Western Australia 1998-2002. Records of the Western Australian Museum, Supplement 66: 343-398.

Hutchins, J.B. and Berry, P.F. (2004). Station map and lists for the diving expeditions (DA1 and DA3). In Jones, D.S. (ed.), Report on the results of the Western Australia Museum/Woodside Energy Ltd. Partnership to explore the Marine Biodiversity of the Dampier Archipelago, Western Australia 1998-2002. Records of the Western Australian Museum, Supplement 66: 7-14-398.

Hutchins, J.B. and Fromont, J. (2004). Station map and list for the workshop diving expedition (DA4). In Jones, D.S. (ed.), Report on the results of the Western Australia Museum/Woodside Energy Ltd. Partnership to explore the Marine Biodiversity of the Dampier Archipelago, Western Australia 1998-2002. Records of the Western Australian Museum, Supplement 66: 15-17.

Hutchins J.B., Slack-Smith, S.M., Berry, P.F. and Jones, D.S. (2004). Methodology. In Jones, D.S. (ed.), Report on the results of the Western Australia Museum/ Woodside Energy Ltd. Partnership to explore the Marine Biodiversity of the Dampier Archipelago, Western Australia 1998-2002. Records of the Western Australian Museum, Supplement 66: 3-5.

Jones, D.S. (2003). The biogeography of Western Australian shallow water barnacles. In Wells, F.E., Walker, D.I. and Jones, D.S. (eds), Proceedings of the Eleventh International Marine Biological Workshop: The Marine Flora and Fauna of Dampier, Western Australia 2: 479. 496. Western Australian Museum, Perth.

Jones, D.S. (2004a). The Burrup Peninsula and Dampier Archipelago, Western Australia: an introduction to the history of its discovery and study, marine habitats and their flora and fauna. In Jones, D.S. (ed.), Report on the results of the Western Australia Museum/ Woodside Energy Ltd. Partnership to explore the Marine Biodiversity of the Dampier Archipelago, Western Australia 1998-2002. Records of the Western Australian Museum, Supplement 66: 27-49.

Jones, D.S. (ed.) (2004b). Report on the results of the Western Australia Museum/Woodside Energy Ltd. Partnership to explore the Marine Biodiversity of the Dampier Archipelago, Western Australia 1998-2002. Records of the Western Australian Museum, Supplement 66: vii-xv, 1-401.

Jones, D.S. (2004c). Barnacles (Cirripedia: Thoracica) of the Dampier Archipelago, Western Australia. In Jones, D.S. (ed.), Report on the results of the Western Australia Museum/Woodside Energy Ltd. Partnership to explore the Marine Biodiversity of the Dampier Archipelago, Western Australia 1998-2002. Records of the Western Australian Museum, Supplement 66: 121-157.

Kohn, A.J. (2003a). Biology of Conus on shores of the Dampier Archipelago. In Wells, F.E., Walker, D.I. and Jones, D.S. (eds), Proceedings of the Eleventh International Marine Biological Workshop: The Marine Flora and Fauna of Dampier, Western Australia 1: 89-100. Western Australian Museum, Perth.

Kohn, A.J. (2003b). The feeding process in Conus victoriae. In Wells, F.E., Walker, D.I. and Jones, D.S. (eds), Proceedings of the Eleventh International Marine Biological Workshop: The Marine Flora and Fauna of Dampier, Western Australia 1: 101-108. Western Australian Museum, Perth.

Kohn, A.J. (2003c). Infaunal invertebrates of an intertidal sandflat, Dampier, Western Australia. In Wells, F.E., Walker, D.I. and Jones, D.S. (eds), Proceedings of the Eleventh International Marine Biological Workshop: The Marine Flora and Fauna of Dampier, Western Australia 1: 109-130. Western Australian Museum, Perth.

McMahon, R.F. (2003). Acute hypo- and hyper-saline responses relative to zonation of intertidal rocky shore and mangrove gastropods from the Burrup Peninsula, Western Australia. In Wells, F.E., Walker, D.I. and Jones, D.S. (eds), Proceedings of the Eleventh International Marine Biological Workshop: The Marine Flora and Fauna of Dampier, Western Australia 1: 131146. Western Australian Museum, Perth.

Marsh, L.M. and Morrison, S.M. (2004). Echinoderms of the Dampier Archipelago, Western Australia. In Jones, D.S. (ed.), Report on the results of the Western Australia Museum/Woodside Energy Ltd. Partnership to explore the Marine Biodiversity of the Dampier Archipelago, Western Australia 1998-2002. Records of the Western Australian Museum, Supplement 66: 293-342.

Morton, B. and Britton, J.C. (2003). The behaviour and feeding ecology of a suite of gastropod scavengers at Watering Cove, Burrup Peninsula, Western Australia. In Wells, F.E., Walker, D.I. and Jones, D.S. (eds), Proceedings of the Eleventh International Marine Biological Workshop: The Marine Flora and Fauna of Dampier, Western Australia 1: 147-172. Western Australian Museum, Perth.

Morrison, P.F. (2004). A general description of the subtidal habitats of the Dampier Archipelago, Western Australia. In Jones, D.S. (ed.), Report on the results of the Western Australia Museum/Woodside Energy Ltd. Partnership to explore the Marine Biodiversity of the Dampier Archipelago, Western Australia 1998-2002. Records of the Western Australian Museum, Supplement 66: 51-59.

Pearce, A., Buchan, S., Chiffings, T., D'Adamo, N., Fandry, C., Fearns, P., Mills, D., Phillips, R. and Simpson, C. (2003). A review of the oceanography of the Dampier Archipelago, Western Australia. In Wells, F.E., Walker, D.I. and Jones, D.S. (eds), 
Proceedings of the Eleventh International Marine Biological Workshop: The Marine Flora and Fauna of Dampier, Western Australia 2: 13-50. Western Australian Museum, Perth.

Peart, R. (2004). Amphipoda (Crustacea) collected from the Dampier Archipelago, Western Australia. In Jones, D.S. (ed.), Report on the results of the Western Australia Museum/Woodside Energy Ltd. Partnership to explore the Marine Biodiversity of the Dampier Archipelago, Western Australia 1998-2002. Records of the Western Australian Museum. Supplement 66: 159-167.

Rota, E., Erséus, C. and Wang, H. (2003). Grania ocarina sp. n., G. darwinensis (Coates and Stacey) comb. n., and other marine Enchytraeidae (Oligochaeta) from the Dampier area, Western Australia. In Wells, F.E., Walker, D.I. and Jones, D.S. (eds), Proceedings of the Eleventh International Marine Biological Workshop: The Marine Flora and Fauna of Dampier, Western Australia 2: 497-512. Western Australian Museum, Perth.

Salotti, M., Griffith, J.K. and Fromont, J. (2004). Other marine invertebrates collected by the diving expedition DA1/98 in the Dampier Archipelago, Western Australia. In Jones, D.S. (ed.), Report on the results of the Western Australia Museum/Woodside Energy Ltd. Partnership to explore the Marine Biodiversity of the Dampier Archipelago, Western Australia 1998-2002. Records of the Western Australian Museum, Supplement 66: 399-401.

Seapy, R.R., Lalli, C.M. and Wells, F.E. (2003). Heteropoda from Western Australian waters. In Wells, F.E., Walker, D.I and Jones, D.S. (eds), Proceedings of the Eleventh International Marine Biological Workshop: The Marine Flora and Fauna of Dampier, Western Australia 2: 513-546. Western Australian Museum, Perth.

Slack-Smith, S.M. (2004). Station map and list for the dredging expedition (DA2). In Jones, D.S. (ed.), Report on the results of the Western Australia Museum/Woodside Energy Ltd. Partnership to explore the Marine Biodiversity of the Dampier Archipelago, Western Australia 1998-2002. Records of the Western Australian Museum, Supplement 66: $19-26$.

Slack-Smith, S.M. and Bryce, C.W. (2004). A survey of the benthic molluscs of the Dampier Archipelago, Western Australia. In Jones, D.S. (ed.), Report on the results of the Western Australia Museum/Woodside Energy Ltd. Partnership to explore the Marine Biodiversity of the Dampier Archipelago, Western Australia 1998-2002. Records of the Western Australian Museum, Supplement 66: 221-245.

Smit, H. (2003). Five new species of the water mite family Pontarachnidae from Western Australia. In Wells, F.E, Walker, D.I. and Jones, D.S. (eds), Proceedings of the Eleventh International Marine Biological Workshop: The Marine Flora and Fauna of Dampier, Western Australia 2: 547-562. Western Australian Museum, Perth.

Tan, K.S. (2003). Feeding ecology of common intertidal Muricidae (Mollusca: Neogastropoda) from the Burrup Peninsula, Western Australia. In Wells, F.E.
Walker, D.I. and Jones, D.S. (eds), Procedings of the Eleventh International Marine Biological Workshop: The Marine Flora and Fauna of Dampier, Western Australia 1: 173-192. Western Australian Museum, Perth.

Taylor, J.D. and Glover, E.A. (2003). Food of the giants field observations on the diet of Syrinx aruanus (Linnaeus, 1758) (Turbinellidae) the largest living gastropod. In Wells, F.E., Walker, D.I. and Jones, D.S. (eds), Proceedings of the Eleventh International Marine Biological Workshop: The Marine Flora and Fauna of Dampier, Westem Australia 1: 225-240. Western Australian Museum, Perth.

Taylor, J.D. and Glover, E.A. (2004) Diversity and distribution of subtidal benthic molluses from the Dampier Archipelago, Westem Australia. In Jones, D.S. (ed.), Report on the results of the Western Australia Museum/Woodside Energy Ltd. Partnership to explore the Marine Biodiversity of the Dampier Archipelago, Western Australia 1998-2002. Records of the Western Australian Museum, Supplement 66: 247-291.

Wells, F.E. and Lalli, C.M. (2003a). Aspects of the ecology of the mudwhelks Terebralia palustris and $T$. semistriata in northwestern Australia. In Wells, F.E., Walker, D.I. and Jones, D.S. (eds), Proceedings of the Eleventh International Marine Biological Workshop: The Marine Flora and Fauna of Dampier, Western Australia 1: 193-208. Western Australian Museum, Perth.

Wells, F.E. and Lalli, C.M. (2003b). Astropecten sumbawanus (Echinodermata: Asteroidea) in Withnell Bay, northwestern Australia. In Wells, F.E., Walker, D.I and Jones, D.S. (eds), Proceedings of the Eleventh International Marine Biological Workshop: The Marine Flora and Fauna of Dampier, Western Australia 1: 209-216. Western Australian Museum, Perth.

Wells, F.E. and Walker, D.I. (2003). Introduction to the marine environments of the Dampier Archipelago. In Wells, F.E., Walker, D.I. and Jones, D.S. (eds), Proceedings of the Eleventh International Marine Biological Workshop: The Marine Flora and Fauna of Dampier, Western Australia 1: 1-12. Western Australian Museum, Perth

Wells, F.E., Walker, D.I and Jones, D.S. (eds) (2003a). Proceedings of the Eleventh International Marine Biological Workshop: The Marine Flora and Fauna of Dampier, Western Australia 1: 1-340. Western Australian Museum, Perth.

Wells, F.E., Walker, D.I. and Jones, D.S. (eds) (2003b). Proceedings of the Eleventh International Marine Biological Workshop: The Marine Flora and Fauna of Dampier, Western Australia 2: 351-698. Western Australian Museum, Perth.

Wilson, N. (2003). Australian Aphelodoris (Mollusca: Nudibranchia): two new species, sperm ultrastructure and a redescription of A. greeni Bum. In Wells, F.F. Walker, D.I. and Jones, D.S. (eds) (2003b). Proceedings of the Eleventh International Marine Biological Workshop: The Marine Flora and Fauna of Dampier, Western Australia 2: 563-587. Western Australian Museum, Perth. 